\title{
Does discontinuous hydration of Senna spectabilis (DC.) H.S. Irwin \& Barneby var. excelsa (Schrad.) H.S. Irwin \& Barneby (Fabaceae) seeds confer tolerance to water stress during seed germination? ${ }^{1}$
}

\author{
Ayslan Trindade Lima ${ }^{4}$, Paulo Henrique de Jesus da Cunha², \\ Bárbara França Dantas ${ }^{3}$, Marcos Vinicius Meiado ${ }^{2 *}$
}

\begin{abstract}
Seed hydration memory is the ability of seeds to retain biochemical and physiological changes caused by discontinuous hydration. This study aimed to determine if Senna spectabilis (DC.) H.S. Irwin \& Barneby var. excelsa (Schrad.) H.S.Irwin \& Barneby (Fabaceae) present seed memory and evaluate the effects of hydration and dehydration cycles (HD) on the seed germination of this species when submitted to conditions of water stress. Seeds underwent HD cycles ( $0,1,2$ and 3 cycles) corresponding to the hydration times X (6 hours), Y (16 hours) and Z (24 hours), determined from the imbibition curve, with 5 hours of dehydration and submitted to water stress conditions. Germination was evaluated at $0.0,-0.1,-0.3,-0.6$ and $-0.9 \mathrm{MPa}$, obtained with polyethylene glycol 6000 solution. Germinability (\%), mean germination time (days) and hydrotime (MPa $\left.\mathrm{d}^{-1}\right)$ were calculated. The seeds of $S$. spectabilis var. excelsa are sensitive to the low osmotic potentials tested in this study, however, when submitted to the HD cycles of 16 hours hydration (time Y), the tolerance to water stress conditions is increased. In addition, the observed benefits on the evaluated germination parameters show that $S$. spectabilis var. excelsa present seed hydation memory.
\end{abstract}

Index terms: Caatinga, seed hydration memory, germinability, abiotic stress, hydrotime.

\section{A hidratação descontínua em sementes de Senna spectabilis (DC.) H.S. Irwin \& Barneby var. excelsa (Schrad.) H.S. Irwin \& Barneby (Fabaceae) confere tolerância ao estresse hídrico durante a germinação?}

\begin{abstract}
RESUMO - Memória de hidratação de sementes é a habilidade que as sementes apresentam em reter alterações bioquímicas e fisiológicas ocasionadas pela hidratação descontinua. Este estudo objetivou determinar se sementes de Senna spectabilis (DC.) H.S. Irwin \& Barneby var. excelsa (Schrad.) H.S.Irwin \& Barneby (Fabaceae) apresentam memória de hidratação e avaliar os efeitos dos ciclos de hidratação e desidratação (HD) na germinação das sementes dessa espécie quando submetidas a estresse hídrico. As sementes passaram por ciclos de HD (0, 1, 2 e 3 ciclos) correspondentes aos tempos X (6 horas), Y (16 horas) e Z (24 horas) de hidratação, determinados a partir da curva de embebição, com 5 horas de desidratação e postas para germinar em condições de estresse hídrico. A germinação foi avaliada nos potenciais 0,$0 ;-0,1 ;-0,3 ;-0,6$ e - $0,9 \mathrm{MPa}$, obtidos com a utilização da solução de polietileno glicol 6000. Foram calculados a germinabilidade (\%), tempo médio de germinação (dias) e tempo hídrico (MPa.d $\left.\mathrm{d}^{-1}\right)$. Sementes de $S$. spectabilis var. excelsa são sensíveis aos baixos potenciais hídricos, porém, quando submetidas aos ciclos de HD no tempo Y (16 horas), há um aumento na tolerância às condições de estresse hídrico. Além disso, os benefícios observados nos parâmetros germinativos mostraram que $S$. spectabilis var. excelsa apresenta memória de hidratação da semente.
\end{abstract}

Termos para indexação: Caatinga, memória de hidratação de sementes, germinabilidade, estresse abiótico, tempo hídrico.

\section{Introduction}

The availability of water in the soil is a fundamental

${ }^{1}$ Submited on: 07/17/2017. Accepted for publication on 10/24/2017. ${ }^{2}$ Departamento de Biociências, UFS, 49510-200 - Itabaiana, SE, Brasil.

${ }^{3}$ Embrapa Semiárido, Caixa Postal 23, 56300-970 - Petrolina, PE, Brasil. condition for the germination process of a non-dormant and viable seed (Popinigis, 1985). The beginning of the seed germination process is characterized by the absorption of water

${ }^{4}$ Programa de Pós-graduação em Ecologia e Conservação, UFS, 49100-000 São Cristóvão, SE, Brasil.

"Corresponding author $<$ meiado@ufs.br $>$ 
and rehydration of tissues that have naturally lost water during seed production (Baskin and Baskin, 2014; Taiz et al., 2017). Tissues rehydration provides an increase in respiratory activities and metabolism reactivation of the seeds, which results in the growth of the embryo (Popinigis, 1985; Taiz et al., 2017).

In arid and semi-arid regions of the world, the availability of water at soil surface presents a restriction of time and space, even during rainy periods of the year, which directly influences seed germination in these environments (Meiado et al., 2012). Not only rehydration of seed tissues can be interrupted due to absence of water in the soil, but seeds can lose absorbed water to the surrounding environment, causing cycles of hydration and dehydration (HD cycles) during imbibition (Fenner and Thompson, 2005; Meiado et al., 2012).

Because of the discontinuous hydration due to HD cycles, seeds of native species to arid and semi-arid regions can present a high survival rate during drought periods, preserving the physiological characteristics resulting from previous hydration, demonstrating that these seeds present a seed memory. Thus, seed memory is the ability of seeds to store biochemical and physiological changes caused by discontinuous hydration (Dubrovsky, 1996; 1998). In addition, discontinuous hydration provides other advantages for the germination process of seeds, such as a significant increase of germination percentage, speed and uniformity, besides the production of vigorous seedlings (Dubrovsky, 1996; 1998; Aragão et al., 2002; Sánchez-Soto et al., 2005; Kaya et al., 2006; Rito et al., 2009; López et al., 2016; Gebreegziabher and Qufa, 2017).

Caatinga is a semiarid ecosystem located in the Northeast region of Brazil and characterized by a deficiency in water availability during a large part of the year and a temporal irregularity in the distribution of rainfall (Queiroz, 2009; Trovão et al., 2007; Santana and Souto, 2011). Many species of plants that inhabit this ecosystem produce seeds that germinate in superficial layers of the soil, where the water resource may be available for a short time and in limited quantity due to the evaporation process, thus subjecting seeds to HD cycles during seed germination (Meiado et al., 2012).

Among Angiosperms families in this ecosystem that are submitted to these environmental conditions, Fabaceae Lindl. presents a great diversity of form, size, color, structure and characteristics of the seeds, and many have important economic value for the Brazilian Northeastern region (Queiroz, 2009; Espírito-Santo et al., 2010). The genus Senna Mill. is part of the Fabaceae family and gathers about 80 species in Brazil. It presents a wide distribution in the Caatinga, being a floristically important genus for this ecosystem (Souza and Bortoluzzi, 2015). Senna spectabilis (DC.) H.S. Irwin \& Barneby var. excelsa (Schrad.) H.S. Irwin \& Barneby is a species popularly known as canafístula, canafistula-de-besouro and cássia-do-nordeste, with distribution concentrated mainly in areas of Caatinga (Queiroz, 2009; Souza and Bortoluzzi, 2015). Seeds of this species have physical dormancy and germinate above $80 \%$ over a wide temperature range, from 15 to $36{ }^{\circ} \mathrm{C}$. However, temperatures between 24 and $27^{\circ} \mathrm{C}$ are those that allow faster germination (Jeller and Perez, 1999). Frequently, this species is found at degraded areas of Caatinga, and has great potential for use in its recovery (Queiroz, 2009). Thus, the objective of this study was to determine the presence of seed memory in S. spectabilis var. excelsa and to evaluate the effects that the discontinuous hydration provides to the seed germination of this species when submitted to conditions of water stress.

\section{Material and Methods}

The study was carried out at the Laboratory of Seed Physiology (LAFISE), at the Federal University of Sergipe, Campus Professor Alberto Carvalho, in Itabaiana, Sergipe. Seed collection was performed on October 26, 2014, in 10 trees of S. spectabilis var. excelsa located in Caatinga areas of the municipality of Brejo Santo (38 $52^{\circ}$ '04.3'W, $7^{\circ} 35^{\prime} 05.2$ 'S and 434 meters of altitude), Southern region of the State of Ceará. This place is characterized by semi-arid climate (Bsh), with maximum temperatures reaching temperatures above $32{ }^{\circ} \mathrm{C}$ in the dry season. The average annual rainfall is about $800 \mathrm{~mm}$ and the rainy season occurs between December and April, during which the production of the fruits of the studied species occurs, with seed dispersal at the beginning of the dry season. (Queiroz, 2009; Climate Data, 2017).

Treatment to overcome seed dormancy: All the seeds of $S$. spectabilis var. excelsa used in this study to the determination of the imbibition curve, dehydration curve and germination tests were previously scarified with sulfuric acid (SigmaAldrich ${ }^{\circledR}$ P.A., $95-97 \%$ ) in glass beakers for 60 minutes to overcome the physical dormancy presented by the seeds of the species. After the period immersed in the sulfuric acid, seeds were washed in running water for 10 minutes and dried on paper (adapted from Jeller and Perez, 1999).

Imbibition curve and dehydration curve: To determine the imbibition curve, four replicates of 25 seeds were weighed on the analytical balance to obtain the initial weight. Subsequently, each replicate was placed in $9 \mathrm{~cm}$ diameter Petri dishes containing two layers of filter paper moistened with $8 \mathrm{~mL}$ of distilled water at a temperature of $25^{\circ} \mathrm{C}$, where each Petri dish represented a repeat. No water was added to the Petri dishes during determination of the imbibition curve. Then, each replication was weighed at 60 -minute intervals, after being placed to imbibition, until they completed 
the germination process with radicle protrusion. After establishing the species imbibition curve, three points in the curve were selected, which were denominated as times $\mathrm{X}, \mathrm{Y}$ and $\mathrm{Z}$, corresponding to $1 / 2$ of phase I, $1 / 4$ of phase II and $3 / 4$ of phase II of the imbibition process, respectively.

To determine the dehydration curve, four replicates of 25 seeds were weighed on the analytical balance to obtain the initial weight. Subsequently, each replicate was placed in $9 \mathrm{~cm}$ diameter Petri dishes containing two layers of filter paper moistened with $8 \mathrm{~mL}$ of distilled water at a temperature of $25{ }^{\circ} \mathrm{C}$ during a period corresponding to the time $\mathrm{Z}$ of the imbibition curve, where the seeds absorb the maximum water before germinating. After hydration on the time $\mathrm{Z}$, the replications were withdrawn from the contact with the water, placed to dry in trays at $25^{\circ} \mathrm{C}$ and weighed on analytical balance at 60 -minute intervals until the weight of the replications returned to the initial weight.

Hydration and dehydration cycles (HD cycles): HD cycles corresponded to pre-germination treatments to evaluate the influence of discontinuous hydration on seed tolerance to water stress. For each time established through the imbibition curve (times $\mathrm{X}, \mathrm{Y}$ and $\mathrm{Z}$ ), the seeds were submitted to 0 (control), 1,2 and 3 cycles of hydration with a dehydration time between each cycle corresponding to the drying time of the seeds obtained through the dehydration curve. As five osmotic potentials were evaluated (see below the description of procedures for assessing water stress), 500 seeds per cycle were required, totaling 2000 seeds for each hydration time. Discontinuous hydration of the seeds was carried out in plastic trays containing two layers of filter paper moistened with $100 \mathrm{~mL}$ of distilled water. For the dehydration phase, seeds were transferred to plastic trays with dry paper and kept at a temperature of $25{ }^{\circ} \mathrm{C}$. Each cycle corresponded to a hydration phase followed by a dehydration phase.

Germination tests and parameters evaluated: Seed germination was evaluated using distilled water (control) and under the osmotic potentials of $-0.1 ;-0.3 ;-0.6$ and $-0.9 \mathrm{MPa}$ obtained with the use of polyethylene glycol 6000 solution (PEG 6000) (Villela et al., 1991) in the stress simulation. For each treatment, four replicates with 25 seeds were used, which were placed to germinate in $9 \mathrm{~cm}$ diameter Petri dishes containing two layers of filter paper moistened with $8 \mathrm{~mL}$ of PEG 6000 solution. The Petri dishes were sealed with parafilm plastic and maintained under white light (12 h photoperiod) and $25{ }^{\circ} \mathrm{C}$. The number of germinated seeds was counted daily during a period of 20 days and radicle protrusion was considered as the criterion for seed germination (Jeller and Perez, 2003).

At the end of the experiment, were calculated using the GerminaQuant software (Marques et al., 2015) the germinability $(\mathrm{G}=\%)$ and mean germination time $[\mathrm{MGT}=$ $\sum n_{i} \cdot t / \sum n_{i}$, where $t_{i}$ is the period between the beginning of the experiment and the nth observation (days) and $n_{i}$ is the number of seeds germinated in the time $i$ (number corresponding to the nth observation) (Labouriau, 1983). Before statistical analysis, the germinability data obtained underwent an angular transformation (arcsine $\sqrt{ } \%$ ).

For each seed lot HD cycle and osmotic potential, percentage of germination was plotted as a function of time and a Boltzman sigmoidal curve was fitted using the software Origin ${ }^{\circledR} 9$, from which the time to achieve $10-90 \%$ germination of the population was estimated. The reciprocal of these times (germination rate) were plotted against osmotic potential (Gummerson, 1986). Linear regressions in each fraction were used to estimate the $\mathrm{x}$-intercept and slope of each regression line. An average of the $\mathrm{x}$-intercept resulted in base osmotic potential $\left(\psi_{\mathrm{b}}\right)$, below which seeds do not germinate (Gummerson, 1986). For each seed lot, the hydrotime $\left(\theta_{\mathrm{H}} \mathrm{MPa} \mathrm{d}{ }^{-1}\right)$ to germination (g) was calculated as: $\theta_{\mathrm{H}}=\left(\Psi-\Psi_{\mathrm{b}}\right) \mathrm{t}_{\mathrm{g}}$, in which $\psi$ is the actual osmotic potential, $\psi \mathrm{b}$ is the base osmotic potential and $\mathrm{t}_{\mathrm{g}}$ is the time since start of imbibition (Gummerson, 1986).

The normality of the data and the homogeneity of the variances were verified through the Shapiro-Wilk and Levene tests. The results were submitted to factorial variance analysis with three factors (hydration time, number of HD cycles and osmotic potential) and the means were compared by Tukey test (Ranal and Santana, 2006). All analyzes were performed in STATISTICA 13 program with $\alpha=5 \%$ (STATSOFT, 2016).

\section{Results and Discussion}

The imbibition curve of S. spectabilis var. excelsa presented a three-phase pattern, with germination occurring at the 28th hour after the initiation of seed hydration (Figure 1A). The hydration times $\mathrm{X}, \mathrm{Y}$ and $\mathrm{Z}$ corresponded to 6,16 and 24 hours, respectively, and imbibed seeds took 5 hours to dehydrate and return to initial weight (Figure 1B). Imbibition curve also presented a three-phase pattern in Poincianella pyramidalis (Tul.) L.P. Queiroz (Dantas et al., 2008a), Schinopsis brasiliensis Engl. (Dantas et al., 2008b) and Bowdichia virgilioides Kunth (Albuquerque et al., 2009).

Seeds of S. spectabilis var. excelsa which did not undergo HD cycles had their germinability influenced as they were submitted to higher water stress conditions, germinating only until the potential $-0.6 \mathrm{MPa}$, showing germinability lower than $20 \%$, and no germination was observed in the potential $-0.9 \mathrm{MPa}$ (Figures 2A, 2C and 2E). However, when these seeds were submitted to HD cycles, an increase in tolerance to water stress was observed, with germination in all evaluated treatments (Figures 2A, 2C and 2E). In addition, germinability 

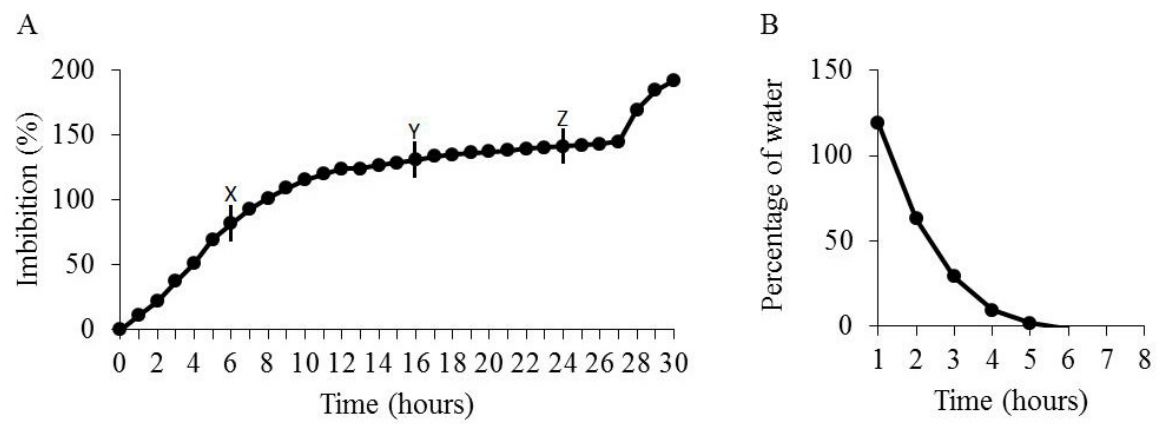

Figure 1. (A) Imbibition curve and (B) dehydration curve of Senna spectabilis (DC.) H.S. Irwin \& Barneby var. excelsa (Schrad.) H.S. Irwin \& Barneby (Fabaceae) seeds.
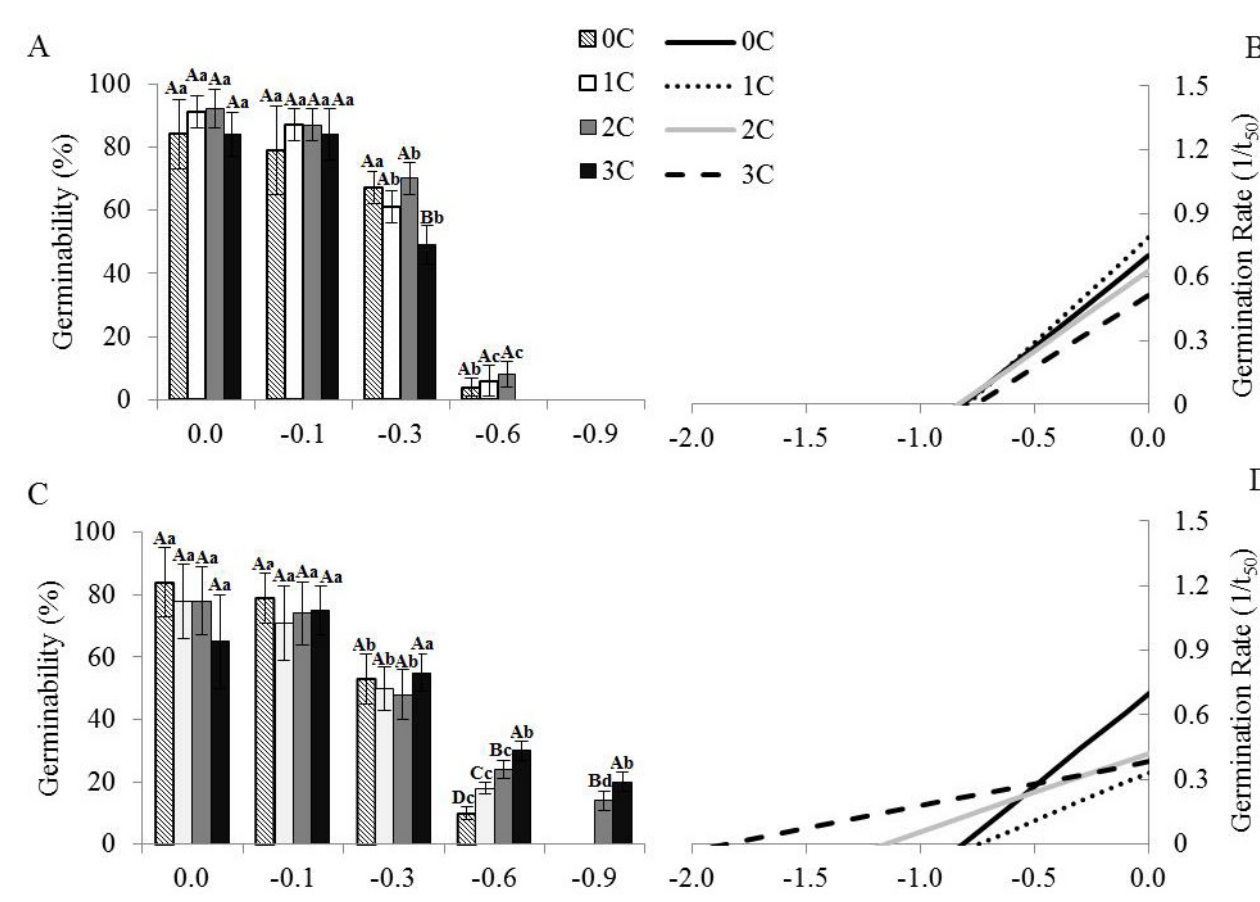

$\mathrm{D}$
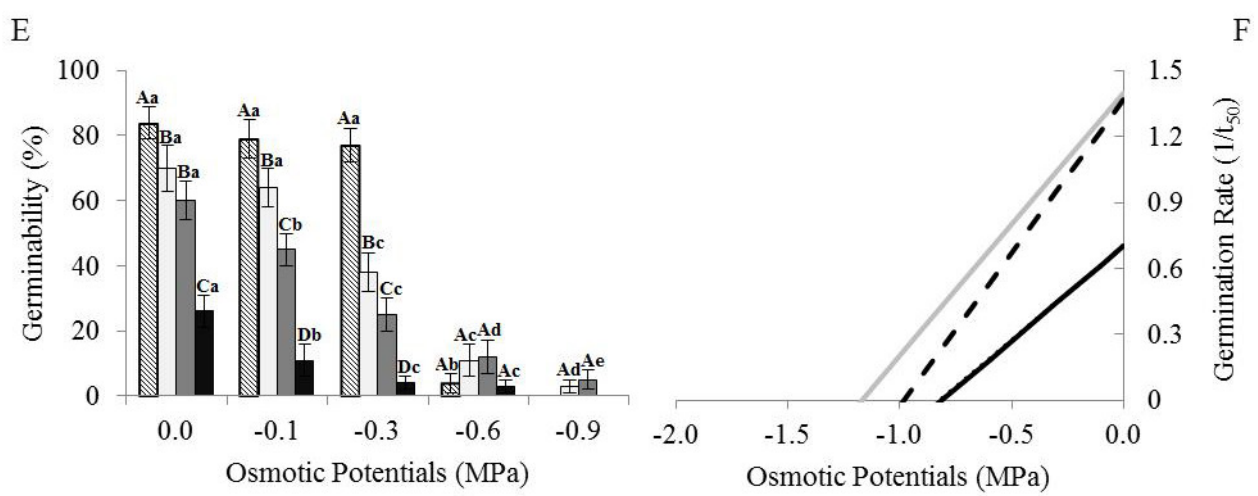

Figure 2. Germinability (\%) and germination rate $\left(1 / t_{50}\right)$ of seeds of Senna spectabilis (DC.) H.S. Irwin \& Barneby var. excelsa (Schrad.) H.S. Irwin \& Barneby (Fabaceae) that passed through 0, 1, 2 and 3 cycles of hydration and dehydration $(0 \mathrm{C}, 1 \mathrm{C}, 2 \mathrm{C}$ and $3 \mathrm{C}$, respectively) in different times of hydration (A and B - Time X: 6 hours, $\mathrm{C}$ and D - Time Y: 16 hours, E and F - Time Z: 24 hours) and were subjected to water stress. In figures A, C and E data were expressed as mean \pm standard deviation. Uppercase letters compare different cycles at the same osmotic potential. Lowercase letters compare the same cycle in different osmotic potentials. 
was also influenced by the different hydration times used in HD cycles $(\mathrm{F}=83.634 ; \mathrm{df}=2 ; \mathrm{p}<0.0001)$.

The reduction of the germinability in $S$. spectabilis var. excelsa with reduction of the osmotic potential can be explained due to the high viscosity characteristic of PEG 6000 and its effects of reducing the solubility and diffusion of the oxygen as the concentration of the solution increases (Hinge et al., 2015), this mean that the increase in the amount of PEG 600 used in the solution to simulate water stress reduced the conditions required for seed germination and, consequently, decreased germinability of the seeds. This reduction of the germinability observed in the seeds of $S$. spectabilis var. excelsa due to higher water stress conditions was also observed in the germination of other tree species that also occur in the Caatinga, as in Simira gardneriana M.R. Barbosa \& Peixoto (Rubiaceae) (Oliveira et al., 2017), Pityrocarpa moniliformis (Benth.) Luckow \& R.W. Jobson (Fabaceae) (Azerêdo et al., 2016), Ceiba glaziovii (Kuntze) K. Schum. (Malvaceae) (Silva et al., 2016), Mimosa ophthalmocentra Mart. ex Benth (Fabaceae) (Nogueira at al., 2017) and Zizyphus joazeiro Mart. (Rhamnaceae) (Lima and Torres, 2009).

Despite the seeds of $S$. spectabilis var. excelsa show sensitivity to water stress, reducing germinability with the reduction of the osmotic potential of the solutions, seeds that were submitted to cycles of HD developed a greater tolerance to the evaluated stress, indicating that the passage through cycles of $\mathrm{HD}$ is fundamental for the development of this capacity to germinate at lower osmotic potentials. As in S. spectabilis var. excels $a$, HD cycles also provided an increase in tolerance to water stress during the germination of seeds of Pilosocereus catingicola (Gürke) Byles \& Rowley subsp. salvadorensis (Werderm.) Zappi (Cactaceae) (Lima and Meiado, 2017), Carthamus tinctorius L. (Asteraceae) (Ashrafi and Razmjoo, 2015), Tanacetum cinerariifolium (Trevir.) Schultz Bip. (Asteraceae) (Li et al., 2011) and $\times$ Triticosecale (Yagmur and Kaydan, 2008).

The increased in tolerance of $S$. spectabilis var. excelsa seeds to low osmotic potentials after going through HD cycles is due to an improvement of the physiological and biochemical events that occur during the germination process of these seeds. This tolerance may be related to the accumulation of LEA proteins during the HD cycles, which are responsible for increasing the tolerance to seed desiccation (Chen and Arora, 2013). Seeds that undergo discontinuous hydration process show protoplasm with lower viscosity and greater permeability to water (Thomas et al., 2000). This may explain the germination of $S$. spectabilis var. excelsa even in higher water stress conditions after going through HD cycles, acquiring the ability to take advantage of the low amount of available water in the lower osmotic potentials.

The MGT of the seeds of the species studied was also significantly influenced by the interaction between cycle, hydration times (6, 16 and 24 hours) and osmotic potentials used in water stress conditions $(\mathrm{F}=34.476 ; \mathrm{df}=18 ; \mathrm{p}<$ 0.0001). This influence can be observed in seeds that did not undergo HD cycles and had their MGT changed from $1.70 \pm$ 0.08 days in $0.0 \mathrm{MPa}$ to $3.57 \pm 0.25$ days in $-0.3 \mathrm{MPa}$ (Table 1 ). However, when they were submitted to HD cycles for 16 hours, the seeds of $S$. spectabilis var. excelsa had their MGT reduced from $8.40 \pm 1.65$, in the case of seeds submitted to one cycle of $\mathrm{HD}$ and placed to germinate at potential $-0.3 \mathrm{MPa}$, to $5.45 \pm$ 0.83 when these seeds went through 3 cycles of $\mathrm{HD}$ and were placed to germinate in the same osmotic potential (Table 1).

The water stress imposed on seeds of $S$. spectabilis var. excelsa which were not submitted to cycles of HD induced an increase on MGT, indicating that the lower osmotic potentials delay the process of imbibing of these seeds. However, when subjected to the HD cycles for 16 hours, the benefit of this treatment on the seeds is evident, because promoted faster water absorption after the HD cycles, reducing its MGT (Table 1). Kaya et al. (2006) in experiments with seeds of Helianthus annuus L. (Asteraceae) also verified the benefit of hydration and drying for these seeds when the MGT was evaluated under conditions of water stress and compared to the seeds of the control group.

The models generated from the seed germination rate of $S$. spectabilis var. excelsa indicated that the $\mathrm{HD}$ cycles provided seeds a greater tolerance to water stress (Figures 2B, 2D and 2F). However, seeds that underwent discontinuous hydration presented a reduction in the germination rate, indicating a delay in the germination process after HD cycles. Among the three hydration times of the HD cycles evaluated in the present study, 16 hours hydration conferred greater tolerance to water stress with the increase of $\mathrm{HD}$ cycles (Figures $2 \mathrm{C}$ and 2D), with a reduction in the $\psi_{\mathrm{b}}$ values from -0.74 in untreated seeds to $-1.85 \mathrm{MPa}$ in seeds submitted to three HD cycles at time Y (Table 2). The benefits provided by the HD cycles with 16 hours hydration are more evident in treatments with higher water restriction, with a 14 and $12 \%$ increase in germination of the seeds submitted to treatments of -0.6 and $-0.9 \mathrm{MPa}$, respectively (Figure 2D).

On the other hand, the HD cycles with only 6 hours hydration did not provide an increase in tolerance to water stress (Figure 2A), and was not observed a significant increase in the germinability of seeds submitted to water stress (Figure 2B). The seeds of $S$. spectabilis var. excelsa that went through the cycles of HD with 24 hours hydration became more tolerant to water stress conditions, being observed a reduction in the value of $\psi_{\mathrm{b}}$ from -0.81 to -1.17 MPa after two HD cycles (Table 2). 
Table 1. Mean germination time (days) of seeds of Senna spectabilis (DC.) H.S. Irwin \& Barneby var. excelsa (Schrad.) H.S. Irwin \& Barneby (Fabaceae) that were submitted to cycles of hydration and dehydration and were submitted to water stress in different osmotic potentials. Data expressed as mean \pm standard deviation. Uppercase letters compare different cycles at the same osmotic potential. Lowercase letters compare the same cycle in different osmotic potentials.

\begin{tabular}{|c|c|c|c|c|c|}
\hline $\begin{array}{c}\text { Time } X \\
(6 \text { hours })\end{array}$ & $0.0 \mathrm{MPa}$ & $-0.1 \mathrm{MPa}$ & $-0.3 \mathrm{MPa}$ & $-0.6 \mathrm{MPa}$ & $-0.9 \mathrm{MPa}$ \\
\hline 0 Cycle & $1.70 \pm 0.08 \mathrm{Bd}$ & $2.42 \pm 0.23 \mathrm{Ac}$ & $3.57 \pm 0.25 \mathrm{Ab}$ & $8.3 \pm 0.57 \mathrm{Aa}$ & - \\
\hline 1 Cycle & $1.37 \pm 0.12 \mathrm{Cc}$ & $2.22 \pm 0.15 \mathrm{Ab}$ & $4.12 \pm 0.78 \mathrm{Aa}$ & $1.75 \pm 3.5 \mathrm{Cb}$ & - \\
\hline 2 Cycles & $1.90 \pm 0.08 \mathrm{Ad}$ & $2.42 \pm 0.09 \mathrm{Ac}$ & $4.22 \pm 0.59 \mathrm{Ab}$ & $6.05 \pm 0.91 \mathrm{Ba}$ & - \\
\hline 3 Cycles & $2.10 \pm 0.11 \mathrm{Ab}$ & $2.42 \pm 0.22 \mathrm{Ab}$ & $4.97 \pm 0.42 \mathrm{Aa}$ & - & - \\
\hline $\begin{array}{c}\text { Time Y } \\
\text { (16 hours) }\end{array}$ & $0.0 \mathrm{MPa}$ & $-0.1 \mathrm{MPa}$ & $-0.3 \mathrm{MPa}$ & $-0.6 \mathrm{MPa}$ & $-0.9 \mathrm{MPa}$ \\
\hline 0 Cycle & $1.70 \pm 0.08 \mathrm{Cd}$ & $2.42 \pm 0.23 \mathrm{Bc}$ & $3.57 \pm 0.25 \mathrm{Bb}$ & $8.3 \pm 0.57 \mathrm{Aa}$ & - \\
\hline 1 Cycle & $2.15 \pm 0.12 \mathrm{Bc}$ & $4.79 \pm 0.99 \mathrm{Ab}$ & $8.40 \pm 1.65 \mathrm{Aa}$ & $4.37 \pm 0.9 \mathrm{Bb}$ & - \\
\hline 2 Cycles & $2.42 \pm 0.09 \mathrm{Bc}$ & $3.82 \pm 0.46 \mathrm{Ab}$ & $6.25 \pm 0.64 \mathrm{Aa}$ & $3.57 \pm 1.12 \mathrm{Bb}$ & $3.50 \pm 4.12 \mathrm{Ab}$ \\
\hline 3 Cycles & $2.80 \pm 0.27 \mathrm{Ab}$ & $4.55 \pm 1.06 \mathrm{Aa}$ & $5.45 \pm 0.83 \mathrm{Aa}$ & $4.05 \pm 0.1 \mathrm{Ba}$ & $3.62 \pm 2.80 \mathrm{Aa}$ \\
\hline $\begin{array}{c}\text { Time } Z \\
\text { ( } 24 \text { hours) }\end{array}$ & $0.0 \mathrm{MPa}$ & $-0.1 \mathrm{MPa}$ & $-0.3 \mathrm{MPa}$ & $-0.6 \mathrm{MPa}$ & $-0.9 \mathrm{MPa}$ \\
\hline 0 Cycle & $1.70 \pm 0.08 \mathrm{Ad}$ & $2.42 \pm 0.23 \mathrm{Ac}$ & $3.57 \pm 0.25 \mathrm{Ab}$ & $8.3 \pm 0.57 \mathrm{Aa}$ & - \\
\hline 1 Cycle & $1.67 \pm 0.05 \mathrm{Ab}$ & $2.50 \pm 0.37 \mathrm{Aa}$ & $3.90 \pm 0.92 \mathrm{Aa}$ & $4.75 \pm 3.31 \mathrm{Ba}$ & $1.25 \pm 1.25 \mathrm{Ab}$ \\
\hline 2 Cycles & $1.25 \pm 0.05 \mathrm{Ba}$ & $1.62 \pm 0.23 \mathrm{Ba}$ & $1.82 \pm 0.55 \mathrm{Ba}$ & $1.30 \pm 0.47 \mathrm{Ca}$ & $1.25 \pm 1.89 \mathrm{Aa}$ \\
\hline 3 Cycles & $1.25 \pm 0.19 \mathrm{Ba}$ & $1.00 \pm 0.71 \mathrm{Ba}$ & $1.50 \pm 1.00 \mathrm{Ba}$ & $2.00 \pm 2.16 \mathrm{Ca}$ & - \\
\hline
\end{tabular}

However, although they become more tolerant after HD cycles, the germinability of $S$. spectabilis var. excelsa seed subjected to HD cycles with 24 hours hydration was significantly reduced in all osmotic potentials evaluated in this study.

The $\theta_{H}$ values were also influenced by the HD cycles in the different hydration times evaluated. Seeds of $S$. spectabilis var. excels $a$ that were submitted to HD cycles with 6 hours hydration had a gradual increase of $\theta_{\mathrm{H}}$ as they were conditioned to a greater number of HD cycles (Table 2). Responding differently to seeds that underwent $\mathrm{HD}$ cycles with 6 hours hydration, those submitted to HD cycles with 24 hours hydration presented a reduction of $\theta_{\mathrm{H}}$ values as the numbers of HD cycles increased (Table 2). After HD cycles with 16 hours hydration, the seeds of $S$. spectabilis var. excelsa presented a reduction in the $\theta_{\mathrm{H}}$ value from the control to one HD cycle, however, the value of $\theta_{\mathrm{H}}$ increased again as the seeds were submitted to higher numbers of HD cycles (Table 2).

The reduction of $\psi_{\mathrm{b}}$ and $\theta_{\mathrm{H}}$ values of $S$. spectabilis var. excelsa that underwent HD cycles and were submitted to conditions of low osmotic potentials indicates that the HD cycles are beneficial at specific hydration times for the species studied and promote the increase of the physiological limit for radicle protrusion, allowing these seeds to germinate at low osmotic potentials such as, for example, at -0.6 and -0.9 MPa. Bradford and Still (2004) attribute the reduction of $\psi_{\mathrm{b}}$ values to the increase of the tolerance of the seeds to the evaluated stress. Casenave and Toselli (2010) also observed, in experiments with melon seeds, a reduction in $\theta_{\mathrm{H}}$ of 0.982 $\mathrm{MPa} \mathrm{d}{ }^{-1}$ in the seeds of the control group to $0.615 \mathrm{MPa} \mathrm{d}^{-1}$ in the seeds that underwent 16 hours of previous hydration.

Table 2. Base osmotic potential $\left(\psi_{\mathrm{b}}-\mathrm{MPa}\right)$ and hydrotime to germination $\left(\theta_{\mathrm{H}}-\mathrm{MPa} \mathrm{d}{ }^{-1}\right)$ of seeds of Senna spectabilis (DC.) H.S. Irwin \& Barneby var. excelsa (Schrad.) H.S. Irwin \& Barneby (Fabaceae) that passed through to cycles of hydration and dehydration $(0,1,2$ and 3 cycles) in the times $X$ (6 hours), Y (16 hours) and Z (24 hours) and were submitted to water stress.

\begin{tabular}{cccc}
\hline Time & Cycle & $\psi_{\mathrm{b}}-\mathrm{MPa}$ & $\theta_{\mathrm{H}}-\mathrm{MPa} \mathrm{d}^{-1}$ \\
\hline $\mathrm{X}$ & 0 & -0.7412 & 1.1630 \\
(6 hours) & 1 & -0.7950 & 1.1133 \\
& 2 & -0.8360 & 1.3308 \\
& 3 & -0.7574 & 1.4686 \\
\hline $\mathrm{Y}$ & 0 & -0.7412 & 1.1630 \\
$(16$ hours $)$ & 1 & -0.8139 & 2.2346 \\
& 2 & -1.1542 & 2.7295 \\
& 3 & -1.8476 & 4.8144 \\
\hline $\mathrm{Z}$ & 0 & -0.7412 & 1.1630 \\
$(24$ hours $)$ & 1 & -0.8180 & 1.1668 \\
& 2 & -1.1699 & 0.8365 \\
& 3 & -0.9812 & 0.7170 \\
\hline
\end{tabular}


This demonstrates that the HD cycles can provide the seeds a rapid water absorption, reducing the time required for the germination process to be completed.

\section{Conclusions}

Seeds of S. spectabilis var. excelsa are sensitive to the low osmotic potentials tested in this study, however, when these seeds are submitted to the HD cycles with 16 hours hydration, their tolerance to water stress conditions increased. In addition, the observed benefits on the evaluated germination parameters show that the seeds of $S$. spectabilis var. excelsa present seed memory.

\section{References}

ALBUQUERQUE, K.S.; GUIMARÃES, R.M.; ALMEIDA, I.F.; CLEMENTE, A.C.S. Alterações fisiológicas e bioquímicas durante a embebição de sementes de sucupira-preta (Bowdichia virgilioides Kunth.). Revista Brasileira de Sementes, v.31, n.1, p.12-19, 2009. http://www.scielo.br/pdf/rbs/v31n1/a28v31n1.pdf

ARAGÃO, C.A.; DANTAS, B.F.; ALVES, E.; CORRÊA, M.F. Sementes de feijão submetidas a ciclos e períodos de hidratação e secagem. Scientia Agricola, v.59, n.1, p.87-92, 2002. http://www. scielo.br/pdf/sa/v59n1/8079.pdf

ASHRAFI, E.; RAZMJOO, J. Seed treatment to overcome salt and drought stresses during germination in safflower (Carthmus tinctorius L.). Journal of Plant Nutrition, v.38, n.14, p. 1-17, 2015. http://dx.doi.org/10.1080/01904167.2015.1069331

AZERÊDO, G.A.; PAULA, R.C.; VALERI, S.V. Germinação de sementes de Piptadenia moniliformis Benth. sob estresse hídrico. Ciência Florestal, v.26, n.1, p.193-202, 2016. http://www.scielo.br/ pdf/cflo/v26n1/0103-9954-cflo-26-01-00193.pdf

BASKIN, C.C.; BASKIN, J.M. Seeds: Ecology, Biogeography, and Evolution of Dormancy and Germination. San Diego: Academic Press, 2014. 1586p.

BRADFORD, K.J.; STILL, D.W. Applications of hydrotime analysis in seed testing. Seed Technology, v.26, n.1, p.75-85, 2004. http://www. plantsciences.ucdavis.edu/bradford/bradford\%20and\%20still-st.pdf

CASENAVE, E.C.; TOSELLI, M.E. Germination of melon seeds under water and heat stress: Hydropriming and the hydrotime model. Seed Science and Technology, v.38, n.2, p.409-420, 2010. https://doi. org/10.15258/sst.2010.38.2.14

CHEN, K.; ARORA, R. Priming memory invokes seed stresstolerance. Environmental and Experimental Botany, v.94, n.1, p.3345, 2013. https://doi.org/10.1016/j.envexpbot.2012.03.005

CLIMATE DATA. Dados Climáticos para cidades mundiais. https:// pt.climate-data.org/. Accessed on: June $26^{\text {th }}, 2017$.
DANTAS, B.F.; CORREIA, J.S.; MARINHO, L.B.; ARAGÃO, C.A. Alterações bioquímicas durante a embebição de sementes de catingueira (Caesalpinia pyramidalis Tul.). Revista Brasileira de Sementes, v.30, n.1, p.221-227, 2008a. http://www.scielo.br/pdf/rbs/ v30n1/a28v30n1.pdf

DANTAS, B.F.; SOARES, F.S.J.; LÚCIO, A.A.; ARAGÃO, C.A. Alterações bioquímicas durante a embebição de sementes de baraúna (Schinopsis brasiliensis Engl.). Revista Brasileira de Sementes, v.30, n.2, p.214-219, 2008b. http://www.scielo.br/pdf/rbs/v30n2/ a27v30n2.pdf

DUBROVSKY, J.G. Discontinuous hydration as a facultative requirement for seed germination in two cactus species of the Sonoran Desert. Jounal of the Torrey Botanical Society, v.125, n.1, p.33-39, 1998. http://dx.doi.org/10.2307/2997229

DUBROVSKY, J.G. Seed hydration memory in Sonoran desert cacti and its ecological implication. American Journal of Botany, v.83, n.5, p.624-632, 1996. http://www.jstor.org/stable/2445922

ESPÍRITO-SANTO, F.S.; SIQUEIRA-FILHO, J.A.; JUNIORMELO, J.C.F.; GERVÁSIO, E.S.; OLIVEIRA, A.M.B. Quanto vale as sementes da Caatinga? Uma proposta metodológica. Revista Caatinga, v.23, n.3, p.137-144, 2010. http://www.redalyc.org/ pdf/2371/237116334020.pdf

FENNER, M.; THOMPSON, K. The Ecology of Seeds. Cambridge: Cambridge University Press, 2005. 250p.

GEBREEGZIABHER, B.G.; QUFA, C.A. Plant physiological stimulation by seeds salt priming in maize (Zea mays): Prospect for salt tolerance. African Journal of Biotechnology, v.16, n.5, p.209-223, 2017. http://www.academicjournals.org/journal/AJB/article-full-textpdf/5B5213762621

GUMMERSON, R.J. The effect of constant temperatures and osmotic potentials on the germination of sugar beet. Journal of Experimental Botany, v.37, n.6, p.729-741, 1986. https://doi. org/10.1093/jxb/37.6.729

HINGE, P.; KALE, A.; PAWAR, B.; JADHAV, A.; CHIMOTE, V.; GADAKH, S. Effect of PEG induced water stress on chlorophyll content, membrane injury index, osmoprotectants and antioxidant enzymes activities in sorghum (Sorghum bicolor (L) (Moench). Maydica, v.60, n.1, p.1-10, M8, 2015. http://www.maydica.org/ ms_601_008.html

JELLER, H.; PEREZ, S.C.J.G.A. Estudo da superação da dormência e da temperatura em sementes de Cassia excelsa Schrad. Revista Brasileira de Sementes, v.21, n.1, p.32-40, 1999. http://www. bibliotekevirtual.org/revistas/RBS/v21n01/v21n01a05.pdf

JELLER, H.; PEREZ, S.C.J.G.A. Condicionamento osmótico na germinação de sementes de cássia-do-nordeste sob estresse hídrico, térmico e salino. Pesquisa Agropecuária Brasileira, v.38, n.9, p.1025-1034, 2003. http://www.scielo.br/pdf/pab/v38n9/18279.pdf

KAYA, M.D.; OKÇU, G.; ATAK, M.; ÇIKILI, Y.; KOLSARICI, Ö. Seed treatment to overcome salt and drought stress during germination in sunflower (Helianthus annuus L.). European Journal of Agronomy, v.24, n.4, p.291-295, 2006. https://doi.org/10.1016/j. eja.2005.08.001 
LABOURIAU, L.G. A germinação das sementes. Washington: Secretaria da OEA, 173p.1983.

LI, J.; YIN, L.Y.; JONGSMA, M.A.; WANG, C.Y. Effects of light, hydropriming and abiotic stress on seed germination, and shoot and root growth of pyrethrum (Tanacetum cinerariifolium). Industrial Crops and Products, v.34, p.1543-1549, 2011. http://www. sciencedirect.com/science/article/pii/S0926669011001786

LIMA, A.T.; MEIADO, M.V. Discontinuous hydration alters seed germination under stress of two populations of cactus that occur in different ecosystems in Northeast Brazil. Seed Science Research, v.27, n.4, p.292-302, 2017. https://doi.org/10.1017/S0960258517000241

LIMA, B.G.; TORRES, S.B. Estresses hídrico e salino na germinação de sementes de Zizyphus joazeiro Mart. (Rhamnaceae). Revista Caatinga, v.22, n.4, p.93-99, 2009. https://periodicos.ufersa.edu.br/ revistas/index.php/caatinga/article/view/1455/pdf

LÓPEZ, L.V.P.; RODRÍGUEZ, A.R.; CORONADO, M.E.S.; HERNÁNDEZ, P.E.M.; SEGOVIA, A.O. Effects of hydropriming treatments on the invigoration of aged Dodonaea viscosa seeds and water-holding polymer on the improvement of seedling growth in a lava field. Restoration Ecology, v.24, n.1, p.61-70, 2016. http:// onlinelibrary.wiley.com/doi/10.1111/rec.12283/epdf

MARQUES, F.R.F.; MEIADO, M.V.; CASTRO, N.M.C.R.; CAMPOS, M.L.O.; MENDES, K.R.; SANTOS, O.O.; POMPELLI, M.F. GerminaQuant: A new tool for germination measurements. Journal of Seed Science, v.37, n.3, p.248-255, 2015. http://www. scielo.br/pdf/jss/v37n3/2317-1537-jss-37-03-00248.pdf

MEIADO, M.V.; SILVA, F.F.S.; BARBOSA, D.C.A.; SIQUEIRA FILHO, J.A. Diaspores of the Caatinga: A Review. In: SIQUEIRA FILHO, J.A. (Org.). Flora of the Caatingas of the São Francisco River - Natural History and Conservation. Rio de Janeiro: Andrea Jakobsson Estúdio, 2012. p.306-365.

NOGUEIRA, N.W.; TORRES, S.B.; FREITAS, R.M.O.; CASTRO, T.H.S.; SÁ, F.V.S. 'Jurema-de-embira' seed germination under water stress and at different temperatures. Revista Brasileira de Engenharia Agricola e Ambiental, v.21, n.4, p.244-248, 2017. http://www.scielo. br/pdf/rbeaa/v21n4/1415-4366-rbeaa-21-04-0244.pdf

OLIVEIRA, F.N.; OLIVEIRA, J.R.; TORRES, S.B.; FREITAS, R.M.O.; NOGUEIRA, N.W. Germination and initial development of Simira gardneriana seedling under water stress and at different temperatures. Revista Brasileira de Engenharia Agrícola e Ambiental, v.21, n.5, p.333-338, 2017. http://www.scielo.br/pdf/ rbeaa/v21n5/1415-4366-rbeaa-21-05-0333.pdf

POPINIGIS, F. Fisiologia da semente. Brasília: s.ed., 1985. 289p.

QUEIROZ, L. P. Leguminosas da Caatinga. Feira de Santana: Universidade Estadual de Feira de Santana, 2009. 443p.

RANAL, M.A.; SANTANA, D.G. How and why to measure the germination process? Revista Brasileira de Botânica, v.29, n.1, p. 1-11, 2006. http://www.scielo.br/pdf/rbb/v29n1/a02v29n1.pdf
RITO, K.F.; ROCHA, E.A.; LEAL, I.R.; MEIADO, M.V. As sementes de mandacaru têm memória hídrica? Boletín de la Sociedad Latinoamericana y del Caribe de Cactáceas y otras Suculentas, v.6, n.1, p.26-31, 2009. http://www.ibiologia.unam.mx/slccs/www/pdf/ Boletin/6_1_ene-abr_09.pdf

SÁNCHEZ-SOTO, B.H.; GARCÍA MOYA, E.; TERRAZAS, T.; REYS OLIVAS, A. Efecto de la hidratación discontinua sobre la germinación de tres cactáceas del desierto costero de Topolobambo, Ahome, Sinaloa. Cactáceas y Suculentas Mexicanas, v.50, n.1, p.414, 2005. http://www.ecologia.unam.mx/laboratorios/dinamica_de poblaciones/cacsucmex/CACTACEAS2005_1.pdf

SANTANA, J.A.S.; SOUTO, J.S. Produção de serapilheira na Caatinga da região semi-árida do Rio Grande do Norte, Brasil. Idesia, v.29, n.2, p.87-94, 2011. http://www.scielo.cl/pdf/idesia/ v29n2/art11.pdf

SILVA, M.L.M.; ALVES, E.U.; BRUNO, R.L.A.; SANTOS-MOURA, S.S; SANTOS-NETO, A.P. Germinação de sementes de Chorisia glaziovii O. Kuntze submetidas ao estresse hídrico em diferentes temperaturas. Ciência Florestal, v.26, n.3, p.999-1007, 2016. https:// periodicos.ufsm.br/cienciaflorestal/article/view/24229/14182

SOUZA, V.C.; BORTOLUZZI, R.L.C. Senna. In: Lista de Espécies da Flora do Brasil. Jardim Botânico do Rio de Janeiro, Rio de Janeiro, 2015. http://floradobrasil.jbrj.gov.br/jabot/floradobrasil/ FB23149. Accessed on: June 26 2017.

STATSOFT. STATISTICA 13. StatSoft South America, 2016. http:// www.statsoft.com.br. Accessed on: June $26^{\text {th }}, 2017$.

TAIZ, L.; ZEIGER, E.; MOLLER, I.M.; MURPHY, A. Fisiologia e desenvolvimento vegetal. Porto Alegre: Artmed, 2017. 858p.

THOMAS, U.C.; VARUGHESE, K.; THOMAS,A.; SADANANDAN, S. Seed Priming - For increased vigour, viability and productivity of upland rice. LEISA India, v.2, n.4, p.14, 2000. http://ileia.fourdigits. $\mathrm{nl} /$ magazines/india/4-monocultures-towards-sustainability/seedpriming-for-increased-vigour-viability-and/at_download/article_pdf

TROVÃO, D.M.B.M.; FERNANDES, P.D.; ANDRADE, L.A.; DANTAS-NETO, J. Variações sazonais de aspectos fisiológicos de espécies da Caatinga. Revista Brasileira de Engenharia Agrícola e Ambiental, v.11, n.3, p.307-311, 2007. http://www.scielo.br/pdf/rbeaa/ v11n3/a10v11n3

VILLELA, F.A.; DONI FILHO, L.; SEQUEIRA, E.L. Tabela de potencial osmótico em função da concentração de polietileno glicol 6.000 e da temperatura. Pesquisa Agropecuária Brasileira, v.26, n.11/12, p.1957-1968, 1991. https://seer.sct.embrapa.br/index.php/ pab/article/view/3549/882

YAGMUR, M.; KAYDAN, D. Alleviation of osmotic stress of water and salt in germination and seedling growth of triticale with seed priming treatments. African Journal of Biotechnology, v.7, n.13, p.2156-2162, 2008. https://www.ajol.info/index.php/ajb/article/view/58938 